\title{
Performing Difference in Front of Death Material, Bodily and Spatial Practice
}

\section{Daria Pezzoli-Olgiati}

\begin{abstract}
«No city is more inclined than Eusapia to enjoy life and flee care. And to make the leap from life to death less abrupt, the inhabitants have constructed an identical copy of their city, underground. All corpses, dried in such a way that the skeleton remains sheathed in yellow skin, are carried down there, to continue their former activities. [...] To be sure, many of the living want a fate after death different from their lot in life: the necropolis is crowded with big-game hunters, mezzosopranos, bankers, violinists, duchesses, courtesans, generals-more than the living city ever contained.» ${ }^{1}$
\end{abstract}

In Highgate Cemetery, as is so typical of the Victorian cemetery, social history and a tangle of individual destinies merge. ${ }^{2}$ Enclosed within walls and fences, graves from two centuries bear witness to people, societies, ideas, and expectations. Some graves are highly visible, located in a prominent place and carefully restored; the stories they tell are known. In other cases, the tombs are silent, overgrown with thick vegetation. Yet although hushed, they are still a presence. Visiting Highgate Cemetery today, one is aware of the sediments of time upon the tombs and their dead. Finding an adequate approach to the richness of this site within an academic reflection is a challenge. How can we unravel the many layers of practices and stories concentrated in such a meaningful place?

\section{Walking through a Victorian Cemetery Today}

In response to this complexity, I propose we explore Highgate Cemetery by taking a walk during which we observe selected memorials and places in both the western and eastern sections. Inspired by key concepts in the

1 Calvino 1974, 199.

2 I wish to express my gratitude to Rona Jonston and Sean Ryan for their help (and patience!) in proofreading this contribution. 
study of religion, this guided tour through the cemetery aims to contribute to the general theme of this volume, the performativity of images.

As places dedicated to the dead, cemeteries are nodes of social and individual transformation. Through the history of European cultures, spaces dedicated to the dead have undergone radical changes. ${ }^{3}$ Considered within the history of religion, cemeteries are quite recent. Victorian cemeteries represent a particular phase in the social handling of the dead that mirrors a general development in European cities in the $19^{\text {th }}$ century. They mark the beginning of delimited, representative public places on the margins of urban settlements. In an era of demographic expansion, and correspondingly greater numbers of deceased, cities faced new challenges.

Several issues contributed to the creation of joint stock companies that brought together knowledge of architecture, landscaping, technological innovation and business acumen to offer a way to bury and remember the dead. ${ }^{4}$ First, space was lacking for additional corpses to be buried in the packed ground around parish churches in growing cities such as London. Furthermore, discussion had turned to hygienic measures and a possible relationship between overcrowded burial grounds and epidemics. In particular, general concerns were focused on the (miasma in parish graveyards and the inauspicious effects it was believed to have on the living population. ${ }^{5}$ In addition, advances in the medical sciences were a product of dissection and academic study that encouraged the stealing of human corpses, or, as it was known at the time, boody snatching.

A final factor was the rigid regulation of burial ceremonies, which were performed only according to the rites of the Church of England. Although they made up a significant part of the London population, Non-conformists were denied a burial place in the Church of England graveyards and their own funerary rituals. In an increasingly diverse society that limitation led to widespread dissatisfaction. ${ }^{6}$ Accordingly, the cemetery companies had a ready market for their wonderful garden landscapes, which were associated with the opportunity to organise burials according to individual convictions, whatever form of Protestantism or religious communi-

3 On this transformation see, for example, Curl 1972; Ahn/Emling/Graf 2011.

4 For an introduction see Rugg 2007; Barker/Gay 1984; Barnard 1990; Rutherford 2008.

5 See Happe 2003.

6 According to Rutherford 2008, 13-23, the religious motives were decisive for creating the new garden cemeteries in England. See also Rugg 2007, 46, and the contribution"The Politics of Death" by Ann Jeffers in this book. 
ty the deceased had been associated with, and even with or without religious ritual. ${ }^{7}$

Highgate Cemetery was opened on 20 May 1839, the third of the cemeteries that would compose the Magnificent Seven, after Kensal Green (1833) and West Norwood (1837). ${ }^{8}$ It belongs among the most impressive of the enterprises of the London cemetery companies. The site was designed to astonish its demanding customers, offering exclusive burial places with names such as the Egyptian Avenue and the Circle of Lebanon. In 1852 the eastern section was opened to enlarge the cemetery and accommodate demand. ${ }^{9}$

More than 170,000 persons are buried in Highgate Cemetery. ${ }^{10}$ In the somewhat less than 200 years of its history, the cemetery has changed greatly, mirroring social transformations in dealing with the dead and death. Once materially magnificent and socially prestigious, by the last decades of the $20^{\text {th }}$ century the West Cemetery had become a place of decay and abandon, rescued only through the enormous efforts of civic organisations, above all the Friends of Highgate Cemetery. Still an active burial ground, the cemetery today allows visitors to experience a revealing chapter of the history of London, either by viewing the tombs of famous individuals or by walking through such an extraordinary site, so often quoted in literature and film, or perhaps by exploring its lush gardens where rare plants and animal species can be found. Diachronic transformations and historical multi-layeredness belong intrinsically to Highgate Cemetery.

From a sociological point of view, the cemetery represents, on the one hand, a social ending. The individual has ceased active membership of society and his or her corpse is now representative of death. In this sense, the cemetery is the terminal station of social and individual interactions. On the other hand, however, the cemetery constitutes a different form of community: it brings together and preserves the dead within a post-mortem society that is more whole and better defined than complex modern societies of the living, where communitization is often fragmented and incomplete. $^{11}$

7 See Sayer 2011.

8 This number is to be understood as largely symbolic since there are more than seven London cemeteries of interest for this time period. See as a guide to the sites Beach 2013; Philpot 2013.

9 See Meller 1994, 153-171.

10 See Bulmer 2014, 8.

11 See Benkel 2012, 87-92, particularly 89; see also Fischer 1996 and Fischer/Herzog 2005. 
This double aspect of a cemetery is particularly telling for the present investigation. This textual guided tour invites the reader to look at Highgate Cemetery as a place where diversity is made visible within a paradox: in a place of memorialization of the deceased, each grave is unique and particular, yet the cemetery as a whole is where the post-mortem community is dwelling and recalled. Now all equal, the dead remind us that mortality is the irrefutable constant of the human condition. The path we will follow leads to selected graves that are then discussed in light of crucial aspects of images as socio-religious practices: the performativity of materiality, the performativity of bodies and the performativity of places, all aspects of visual performativity.

\section{Materiality at Work}

Our tour begins with a general view of graves in the eastern part of the cemetery (fig. 1). Immediately the variety in styles of memorial is evident; crosses, angels, and simply formed gravestones with or without decoration. They also appear to have been erected at different times. Despite all of these differences, they share one fundamental trait: all are made of solid material and therefore all have a strong plastic presence in the landscape of the cemetery.

The grave materialises a presence that is ambiguous. The person remembered by the grave is dead, absent, yet the very material presence of the tomb marks the dead body and recalls the person as formerly a living member of a family and of a social group. By means of its materiality, the grave locates the dead body as well as the memory of the deceased individual, of that person's life and relationships.

The tomb marks a threshold between the presence of the corpse and the absence of the living person. ${ }^{12}$ As we analyse a memorial as a material artefact, the link to an anthropological concept of the image can be illuminating. ${ }^{13}$ The image is then understood as the result of a complex relationship between the visually perceived artefact (in our case the grave), the mental images it evokes (for instance, the memory of the deceased or the general

12 Macho highlights the significance of material representations of the dead in the history of culture and particularly of art. Citing Paul Ludwig Landsberg, he writes, «The status of the dead person is paradoxical. He embodies the presence of someone who is absent. It is not death that [...] is spresent for us in absence> but the deceased, the corpse.» (Macho 2000, 99, translation by the author).

13 Belting 2011. 


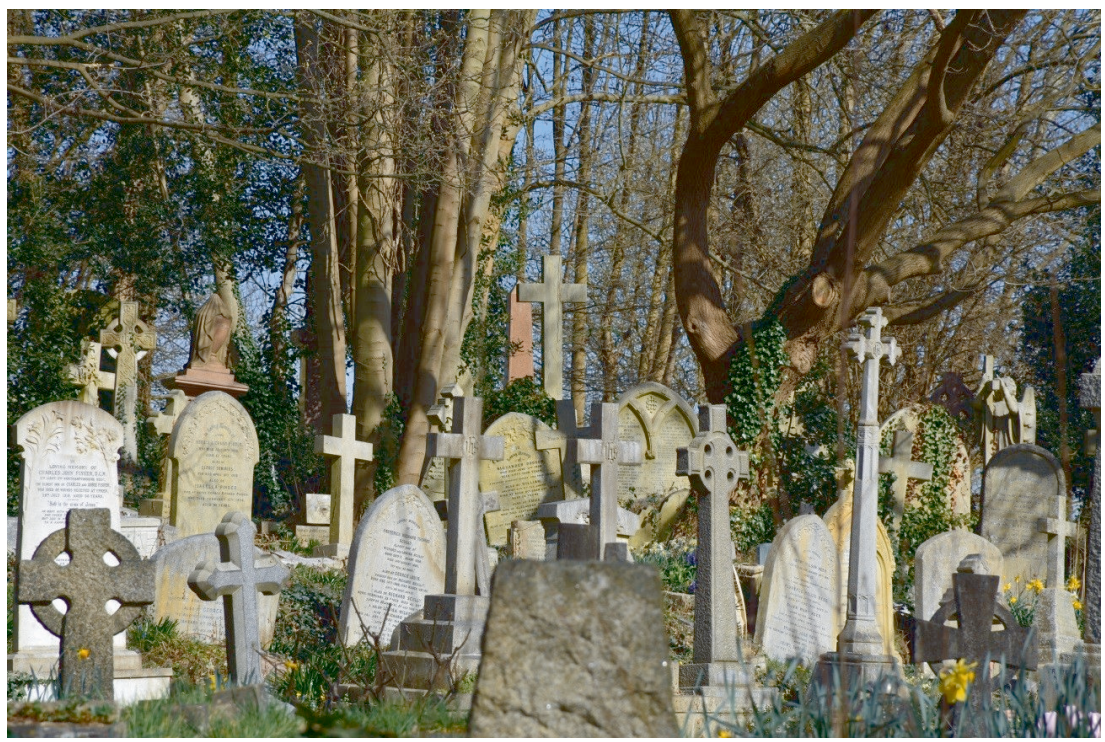

Fig. 1: Graves in the East Cemetery (Image: Daria Pezzoli-Olgiati 2018).

idea of mortality as the human destiny $)^{14}$ and the bodies encapsulated in its materiality (the dead body, the imagined living person and, of course, the visitor.) The materiality of the tombs marks this relationship, articulating the tension between presence and absence, between visible and invisible, and between the immanent spatial dimension within the cemetery and the transcendent dimension of the realm of mental images, concepts or religious orientation. The performativity of a grave has to do with communication processes by means of materiality that arise whenever somebody looks at the artefact and connects the memorial with mental images,

14 Macho 2000, 93, is critical of the universalisation of death: «[T]he anthropological universalisation of death usually presupposes an operation whose legitimacy is suspect: it identifies the concept of death with the concept of mortality» (translation by the author). I hold that death can be seen as an anthropological constant, an issue with which societies have to deal because human beings as biological organisms are mortal. From an emic perspective, in the European context of the 19th century and still today, death was and is universalised as a general phenomenon for the human being and the individual. This can be seen for instance in the various visual representations of death as a skeletal figure waiting for new victims. For a comparative overview of approaches to death in the history of religions and cultures see van Barloewen 2000. 
concepts, ideas and expectations by means of that gaze. The articulation of that potential communication depends on the nature of the grave.

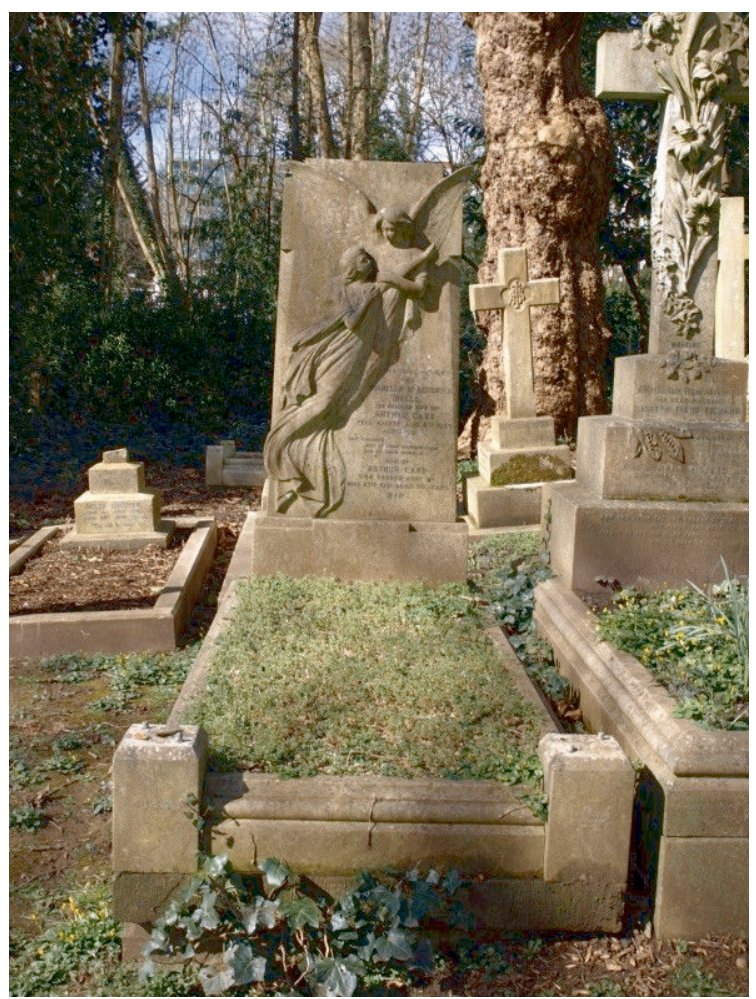

Fig. 2: Grave of Isabella (Belle) McKendrick and Arthur Care, East Cemetery (Image: Daria Pezzoli-Olgiati 2018).

I deepen this approach by considering the tomb reproduced in fig. 2. An angel is accompanying a woman towards heaven. The floating clothes of both figures suggest that they are flying through the air. The epitaph identifies the woman:

IN LOVING MEMORY OF

ISABELLA MC KENDRICK (BELLE)

THE BELOVED WIFE

OF ARTHUR CARE

FELL ASLEEP AUG. $8^{\text {th }} 1925$.

AGED 59. 
NOT GOODBYE

BUT IN SOME HAPPIER CLIME

BID US GOOD MORROW

AND OF ARTHUR CARE

WHO PASSED AWAY

ON MAY $23^{\text {rd }} 1931$ AGED 66 YEARS.

$\mathrm{R} \cdot \mathrm{I} \cdot \mathrm{P}$

The words relate that the husband died almost six years after his wife and was buried in the same place. The bas-relief expresses the continuity between death and afterlife. Isabella and the angel are flying to an otherworldly sphere. The euphemism «fell asleep» emphasises a conception of death as a passage from the immanence of this world to an otherworldly place where «we» (the couple? the visitors of the grave?) will meet again. The end is not an end point but just a phase. Combining image and text, the gravestone refers to a belief in eternal life, recalling widespread religious ideas of angels, heavens and otherworldly sites. In this case, the visitor can detect a Christian framing, whereby grief is linked with hope, in the expectation of meeting again in the afterlife. Here the materiality of the grave acts as a marker on the path between life and afterlife, its religious significance explicit in the link to a tradition and to a symbol system.

The reference to continuity between life before death and life after death is expressed differently in the next example (fig. 3). This much more recent gravestone is made of a dark stone slab pierced through in the centre about one third from the top. The margins of the hole have been crafted into the form of a star, with the star shape highlighted in gold. Under the star, five words, in the style of handwriting, are aligned on the vertical axis:

\section{Star \\ Shining \\ Radiant \\ Eternally \\ Bright}

The sculptural and textual composition suggests a comparison between the deceased women (Geraldine) and a star: the qualities of the star can apply to her as a living person but also to an idea of eternal life after death. They could also refer to her eternal memory. On a visual level, the sculpture combines the materiality of the carved stone with the void of the hole in the centre of the star. Furthermore, it stages the contrast between presence and absence by opposing the dark colour of the raw stone with the golden 


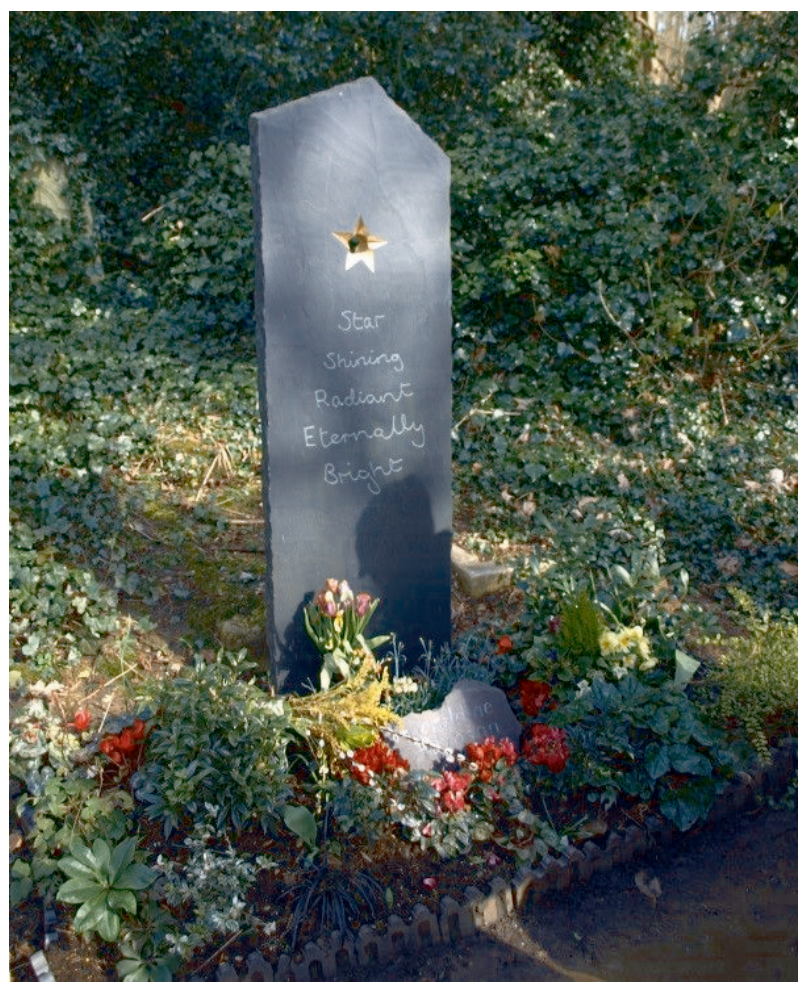

Fig. 3: Grave of Geraldine Adamson, East Cemetery (Image: Daria Pezzoli-Olgiati 2018).

light of the celestial body. The gravestone makes no clear reference to a precise cosmic image of the world. Here, the gravestone marks the limit between the darkness of death and the light of a star. By remaining open to interpretation, the grave actively engages the visitor, inspiring varied interpretations of death and afterlife.

By contrast, the gravestone in fig. 4 resists the idea of death as a passage between being in this world and an otherworldly existence. The sculpture was designed by the artist Patrick Caulfield, who was buried here in 2005 . In this case, the memorial materialises the idea of death as an everlasting condition. The letters «D - E - A - D» form steps; the reading direction indicates a falling stair. Like the gravestone in fig. 3, the sculpture plays with the contrast between a concrete presence, here of the dark stone, and a void, here created in the letters. This tomb marks distinctly the separation of life and death: the visitor is on the side of the living, the remains of 


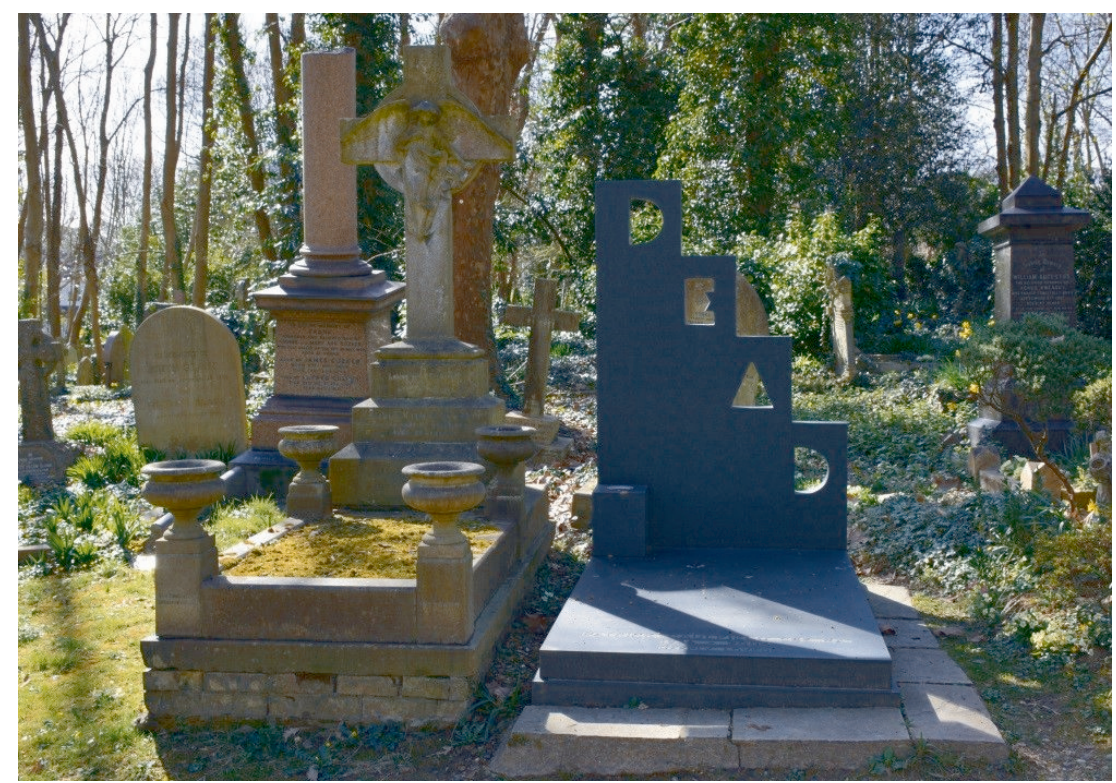

Fig. 4: Grave of Patrick Caulfield, East Cemetery (Image: Daria Pezzoli-Olgiati 2018).

Patrick Caulfield belong to the community of the dead. This sculpture stages mortality and finitude in a radical way. Furthermore, it demands the involvement of its viewer, who is to assume the role of reader. The stele as a work of art is entirely tautological, fixing the references explicitly by means of the design and performing the end of human life. At the same time, as an artefact designed by the deceased himself, the sculpture enacts the relationship between artist and work, with the latter surviving the former and, in a sense, rendering him imperishable.

The materiality of a grave affects its viewers, engaging them in a communication process and demanding interpretation. Depending on the visual and sculptural programme, the relationship between the visitor and the deceased person, and the bond between the material representation and the references, the mental image varies. The dynamics of interpretation contribute to the continuous transformations of a cemetery. Such material communication keeps alive the culture of burials that was initiated in the $19^{\text {th }}$ century and remains an option within today's methods of dealing with death and the dead. This communication enables the memory of 
the deceased to endure while also establishing finitude as a fundamental trait of the human condition. ${ }^{15}$

The material dimension of a grave has been the starting point for our tour through the cemetery. The concreteness of a memorial prescribes how the living and the dead communicate. The memory of the dead, their body invisible, is incarnated in the stone. The materiality of the memorial ascribes the memory of the deceased with a three-dimensional, spatial presence.

\section{Bodily Encounters}

At the second station of our imaginary walk through Highgate Cemetery, our reflection focuses on the bodily dimensions implied by a grave. Viewed through this lens, the memorial appears even more paradoxical, for it makes visible an invisible corpse and attributes perenniality to a body that immediately upon death has begun to degenerate.

The corporeal performance of a grave is manifold. ${ }^{16}$ By visiting a memorial, by looking at the sculpture, the body of the visitor engages in a communication process mediated by materiality. In this exchange between bodies - the living body of the visitor, the lifeless body of the deceased, and the material body of the memorial - the gaze is crucial. According to Gottfried Boehm, the eye links the human to the world and also to himself or herself. In the context of visual studies, Boehm correlates the eye to selfreflexion and an associated twofold capability: «to see and yet to watch oneself». ${ }^{17}$ In this way, the body of the visitor meets the body of the deceased. This idea of encounter is plastically represented in the recurring motif of clasped hands, often accompanied by the inscription «We shall meet again». In fig. 5 the motif is prominently placed on an upper socle of the memorial dedicated to William Thomas Barrow and other members of his family that is located in the western part of Highgate Cemetery. The clasped hands anticipate an imaginary afterlife encounter between members of the family. On a visual level, this corporeal contact takes place in the moment in which the visitor looks at the bas-relief.

15 On the concept of memory and its link to materiality see Assmann 2010.

16 For the concept of corporeal performativity, particularly in religious symbol systems, see Ornella/Knauss/Höpflinger 2014.

17 «Selbstreflexion meint eine doppelte menschliche Befähigung: zu sehen und sich selbst dabei zuzuschauen", Boehm 2001, 39-40 (translation from the German original by the author). 


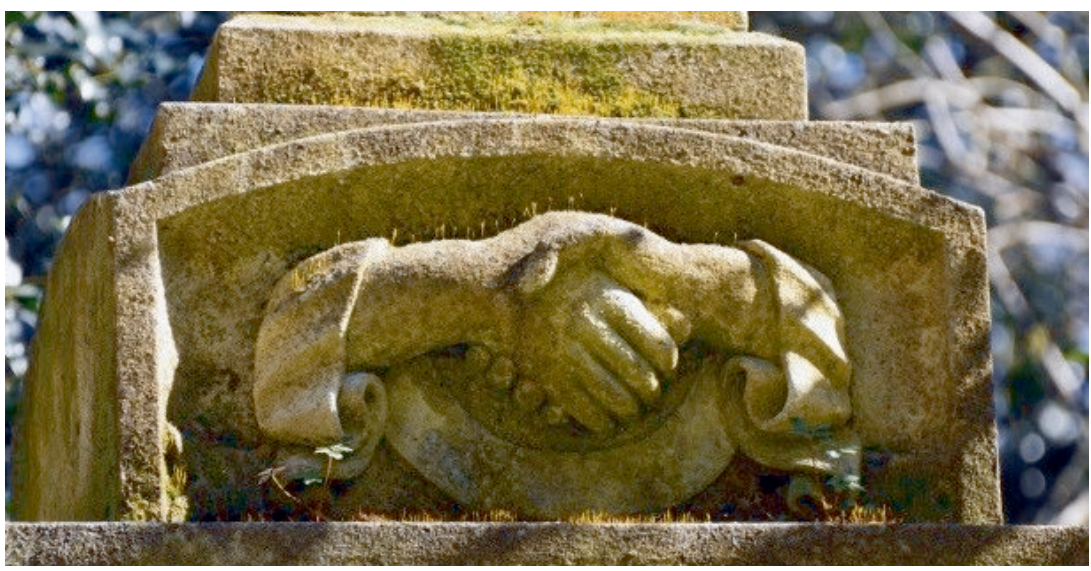

Fig. 5: Family grave of William Thomas Barrow, West Cemetery (Image: Daria Pezzoli-Olgiati 2018).

In the complex composition of the grave, this sculptural connection of stone hands transmits the immediacy of bodily contact, a desire that is unrealisable when sensed before a grave. The depicted contact is a reminder of the barrier between life and death, and of the radicality of the dissolution of the body and the impossibility of any direct contact with the dead person. In the gravestone reproduced in fig. 6, the inscription locates the encounter between the imagined bodies, portrayed in the chiselled hands, in a Christian eschatological context:

\section{THE CUP WAS BITTER THE STING SEVERE \\ TO PART WITH ONE I LOVED SO DEAR \\ MY TROUBLES WERE GREAT I WILL NOT COMPLAIN \\ BUT TRUST IN CHRIST TO MEET AGAIN.}

The text is written as a retrospective on the time of grieving and ends looking forward to a future reuniting in Christ. The ribbon of ivy, an evergreen, emphasises the ideas of immortality and eternity as well as friendship, fidelity and marriage. ${ }^{18}$

18 In the Victorian era flowers and plants were used as a language following precise rules and significations that were diffused in magazines and books. See Greenaway 1884, 23, for the symbolism of ivy. See also Lehner/Lehner 1960, 119; Seaton 1995, 180-181; Chwalkowski 2016, 245-246. See also the contribution by Ann Jeffers in this book, "Animal, Vegetable or Mineral?».

https://doi.org/10 5771/9783845294520-53, am 26.04.2023, 15:19:00 


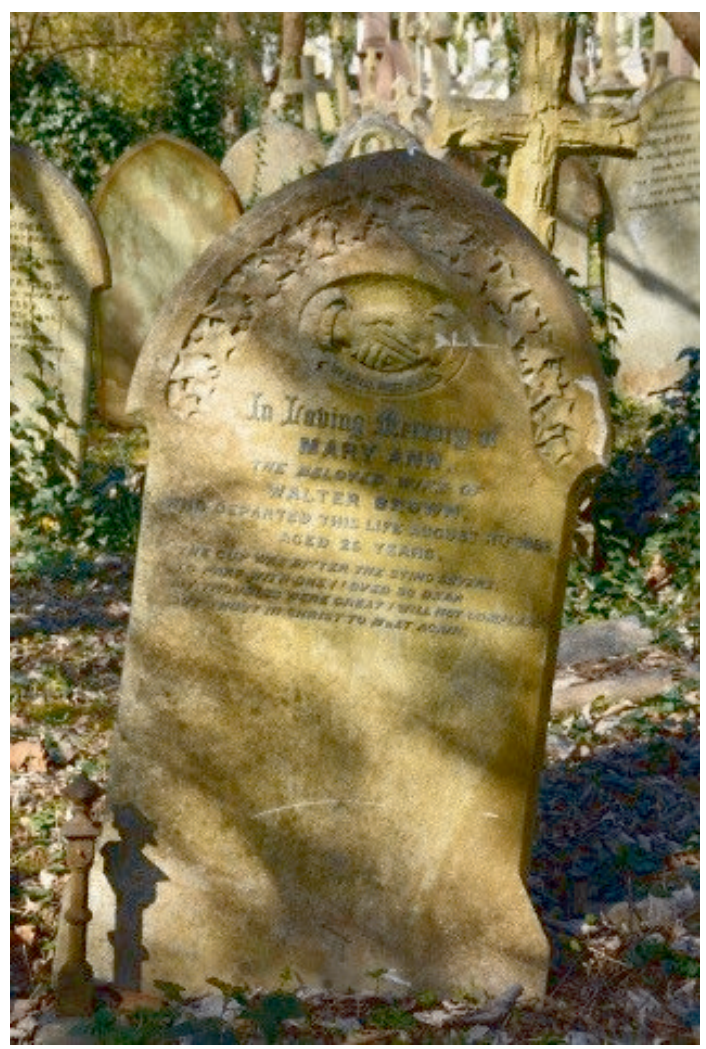

Fig. 6: Grave of Mary Ann Brown, East Cemetery (Image: Daria Pezzoli-Olgiati 2018).

Photography is an additional, and widely used, visual medium that allows an imagined encounter between the viewer and the deceased. The relationship between this medium and death is striking, an affinity that has been formulated by Hans Belting thus: «?t?he new picture that so emphatically held evidence of life in fact produced a shadow of life. [...] One can no longer quit one's own image: it does not hold on to the life that it depicts, or holds on to it in such a contradictory manner that the life quickly escapes out of it». ${ }^{19}$

19 Belting, 2000, 170: «Das neue Bild, das so emphatisch den Beweis des Lebens führte, produzierte in Wahrheit einen Schatten des Lebens. [...] Man kann sein eigenes Bild nicht mehr verlassen: es hält das Leben nicht fest, das es aufzeichnet, 
The photograph reproduced in fig. 7 is a portrait of Mounira (Mary) Desira, who is buried in the eastern part of Highgate Cemetery. This picture is a materialised memory of the dead woman, with the photograph attributing to her a unique visual identity.

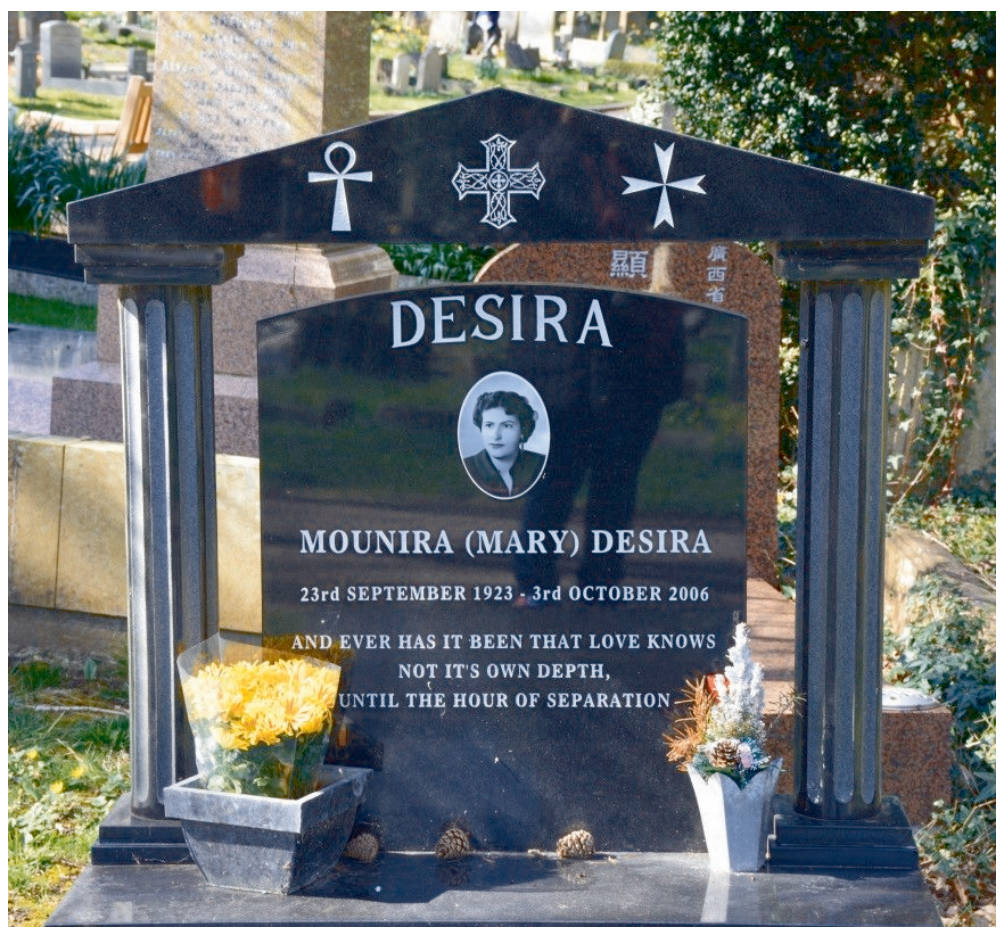

Fig. 7: Grave of Mounira (Mary) Desira, East Cemetery (Image: Daria Pezzoli-Olgiati 2018).

The photograph, which appears to have been professionally produced, depicts her in the middle of her life (possibly aged between 40 and 50) and condenses the biography of a person who lived for over 83 years into one particular moment of that life, the instant in which the picture was taken. ${ }^{20}$

oder hält es so widersprüchlich fest, dass das Leben rasch aus ihm entweicht» (translation from the German original by the author).

20 On the relationship between image and metaphor see Boehm 2001, 30. 
The photograph defines the encounter with the occupant of the grave and constantly updates the presence of the invisible body. Paradoxically, the immediacy of the portrait also expresses the ephemeral nature of life: the picture captures only an instant of a life, an instant that immediately became part of the past. The portrait on the gravestone materialises the memory of the dead woman, but in so doing it anchors her in the past.

The composition of the memorial as a whole reinforces the fleeting nature of life as evoked by the photograph. An Ankh cross, a Coptic cross and a Maltese cross make reference to an Egyptian Christian background. Death and life converge in the cross, the central symbol of Christianity. The literary lines on the lower part of the memorial emphasise the impact of the death through recognition of what has been lost. ${ }^{21}$

In the encounter between viewer and grave, the body of the deceased is transitorily re-established in the form of a memory of a living person. The meeting of the bodies of the living and of the dead, an encounter mediated by the materiality of a (selected) sculptural motif or a photograph, complicates the entangled linking of presence and absence that the grave articulates and locates within the cemetery.

\section{Graves as Multi-layered Places}

As noted, our guided tour to select memorials in Highgate Cemetery is designed around an anthropological approach to images that are understood here as dynamic communication processes: the materiality of the grave interacts with the visitor who looks at it. In the exchange between viewer and work, meanings are produced; in this process, the dead body, the sculpture as a body, and the viewer, understood as a living body, are interrelated. The third station of this walk takes us to the spatial dimension, which makes possible this «corporeal» exchange. If we are to probe further to establish how images perform as socio-religious practices in a cemetery, we must add to our reflections on what materiality does and how the bodies involved interact with that materiality consideration of the locus where the triangulation between materiality, mental images and the body takes place.

Carla Danani describes spatiality as the basis of existence: «Human life is an existence within, and through, spatiality because it is a life in, and

21 The epitaph contains a quotation from the first chapter of Kahlil Gibran's The Prophet, entitled «The Coming of the Ship», Gibran 1923, 5. 
through, a conscious body: it perceives, acts and moves around by having a certain grip on space that allows the human being orientation and to be located. [...] Human beings, therefore, like things, are always somewhere [...]. Though human beings and things have different relationships with the places they occupy. We can say of the human being that in a strict sense it inhabits.» In deploying the verb «to inhabit», Danani highlights the transient locating of human bodily existence. ${ }^{22}$ With this link between spatiality and body, temporal transiency assumes intensified significance within the cemetery and in front of the grave.

Sociologist Thorsten Benkler has summed up the cemetery since the $19^{\text {th }}$ century as «the $<$ located $>$ culmination of the sepulchral development in modernity. ${ }^{23}$ His approach to the modern cemetery arises from a recognition that cemeteries mirror changes in the social significance of death and in approaches to death. He points out that there is a substantial difference between death as a biological process and death as a social phenomenon. Only when the deceased's remains lie in the grave are the survivors able to deal with the dynamics of death. ${ }^{24}$ "To be buried in a cemetery means having overcome the problem of death〉 as a personal problem. ${ }^{25}$ According to Benkler, the grave is first of all the place where the deceased is integrated into the community of the dead. He defines the grave as a «topographically framed signifying construction.» ${ }^{26}$

In the context of our tour, which is an (imagined) spatial practice in itself, the cemetery as a place produces meaning; the spatial extension of the grave and the cemetery, the latter a delimited site holding the entire postmortem community, locates both the remains of the deceased and encounters between those living in society and the idealised society of all the dead. Place is here also understood as a dimension of visual performativity, for it complements the materiality of an image. Or, in other words, the extension of every materialisation of a mental image has volume, which means that visual communication is always realised in place. Within the performative approach to Highgate Cemetery articulated in the studies collected

22 Danani 2013, 19-20 (translation from the Italian original by the author).

23 «[...] das «verräumlichte» Kulminat der Sepulkralentwicklung der Moderne», Benkel 2012, 9 (translation from the German original by the author).

24 Benkel 2012, 8-11.

25 Benkel 2012, 37.

26 «Er [der Friedhof] ist ein topographisch gerahmtes Sinnkonstrukt»; Benkel 2012, 42. 
in this volume, spatiality can be engaged in different forms, by considering the physical, social and symbolic dimensions of space. ${ }^{27}$

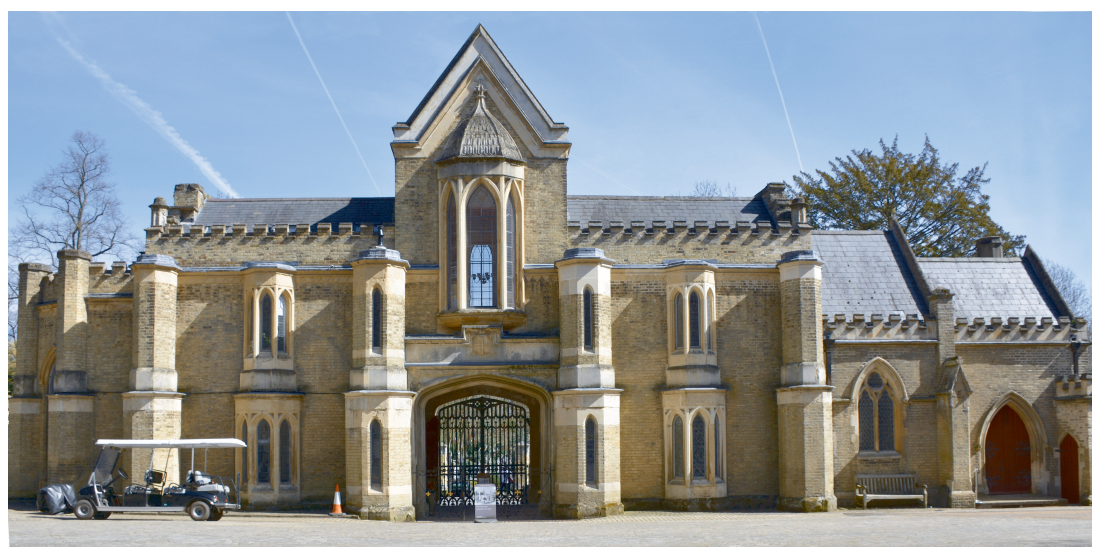

Fig. 8: Entrance to the West Cemetery, captured from the interior courtyard (Image: Daria Pezzoli-Olgiati 2018).

As a physical location, Highgate Cemetery appears to be a clearly delineated site. Access to Highgate Cemetery East and Highgate Cemetery West is regulated by an entrance to each cemetery. The Victorian access building to the western cemetery, situated at Swain's Lane, preserves the original layout designed by Stephen Geary, founder of the company, architect and entrepreneur, ${ }^{28}$ with only a few changes. The entrance gate is in the middle of the building, which contains a chapel for Anglicans and a chapel for Non-conformists (in fig. 8, on the right and left respectively). The entrance to the eastern cemetery is also regulated by a gate. Both sites are enclosed by walls or fences (fig. 9). Although some of the western sections are overgrown (and recall a wild forest more than an English garden), Highgate Cemetery was conceived as a precisely designed landscape that took advantage of its favourable elevated position and some pre-existing elements like the cedar tree that was then integrated into the Circle of Lebanon. ${ }^{29}$

27 On space and its sociological significance see Löw 2001. See also the contribution by Carla Danani in this volume.

28 Bulmer 2014, 14.

29 Meller 1994, 155. See also the contribution by Alberto Saviello in this volume. 


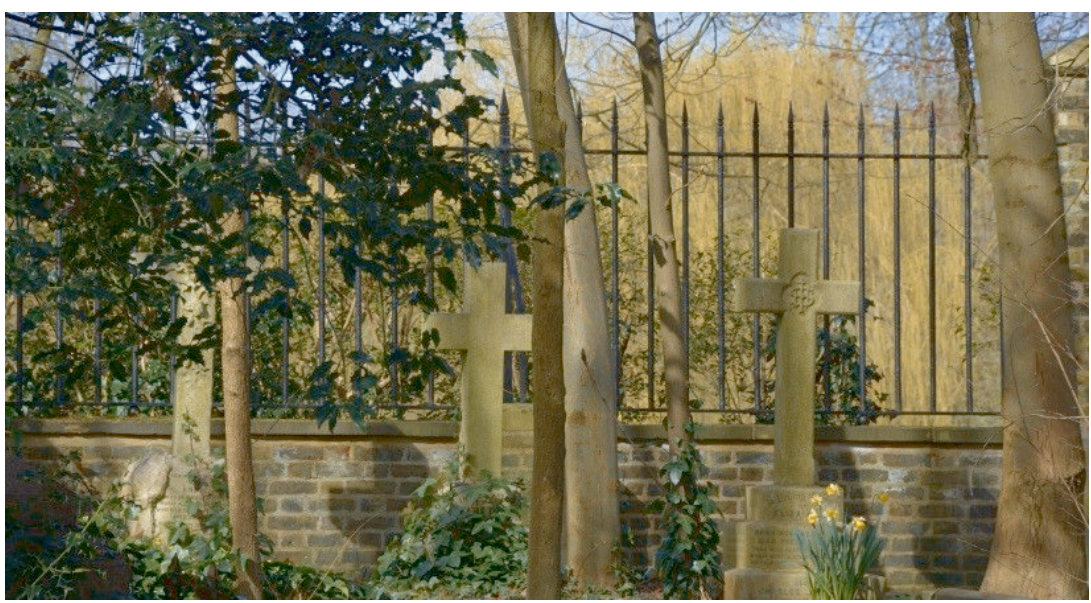

Fig. 9: The fence delimiting the East Cemetery towards the north (Image: Daria Pezzoli-Olgiati 2018).

The planning of the cemetery in the $19^{\text {th }}$ Century which sought to realise new ideas about burials and sepulchral post-mortem culture, together with today's approach to the cemetery as both a historical site and a burial site, belong to the second layer of spatial meaning making. The social dimension of a place concerns relationships within the communities that inhabit and shape a given area. Walls and fences detach and isolate the cemetery from the outer urban settlement. By means of gates, the transition into and from the cemetery can be controlled. Lanes, stairs, and monumental landscape elements like the Egyptian Avenue or the Terrace Catacombs as well as the many unpretentious small paths determine the routes to different parts of the cemetery, the accessibility of certain memorials, and movement through the whole area.

In the eastern part the graves appear to be arranged according to ideological, religious or national belonging (for example, the graves of many fellow communists are close to the memorial of Karl Marx and his wife, Jenny von Westphalen). In the western section, by contrast, the division between Anglicans and Non-conformists is very distinct and has been clearly marked since the foundation of the cemetery. As noted above, the ability to dedicate part of the cemetery for the burial of Non-conformists was a crucial impetus for the creation of Victorian cemetery companies. 
Although the specific area was small, its existence allowed religious diversity within the cemetery. ${ }^{30}$

The layout, internal organisation, division and siting of the cemetery within a general urban design should not be considered only in light of the physical and social dimensions of space. Each aspect also has symbolic meaning. We have noted that the cemetery exists also as an enclosed community of the dead. In this location, this «other» society is not only protected (for example, from the body-snatchers of the Victorian era) but also kept together and separated distinctly from the urban community. The cemetery locates death and thus symbolically elaborates the finitude of human life. At the same time, it articulates difference: ${ }^{31}$ each memorial refers to the former life of the person or persons it commemorates and mirrors their individual, familiar and social position in an idealised way. In the quiet garden cemetery the men and women who lie side by side may have lived and died almost 200 years apart. Different generational, gender, religious, ideological and national identities are very visible in the memorials but they are harmonised through their belonging to the same physical, social and symbolic territory.

Consideration of the spatiality of the cemetery as a whole is thus illuminating, but so too is the small-scale spatial approach that looks at single graves. As our tour comes to an end, we can pause to reflect on two specific memorials in light of spatial performance.

Fig. 10 depicts the memorial of Harry Thornton, a pianist who was born in 1883 and died in 1918, a victim of the influenza pandemic. ${ }^{32}$ His grave is unique. The form of a grand piano stands out in this part of the East Cemetery, where it is located next to traditional crosses and plain headstones. Like each and every memorial, this particular grave marker indicates both the location where its subject was buried and that person's position within the community of the living. Other than his name, the memorial reveals no information about Thornton. The piano makes

30 «They [the cemeteries] were usually divided religiously into sections dedicated to various denominations, and socially by sections dictated by the price of the grave plots», Rutherford 2008, 5.

31 «Not only does each monument, tomb or gravestone pinpoint the location of a grave, but its decoration, material, design and position within the Cemetery can indicate the deceased's position in society. At Highgate, one of the London Cemetery Company's rules even stipulated that plots purchased within 20 feet $(6 \mathrm{~m})$ of a pathway had to be marked with a monument, whereas simpler, smaller gravestones were allowed at greater distance», Bulmer 2014, 26.

32 https://highgatecemetery.org/visit/who\#music (accessed June 14, 2018). 
Thornton's profession the marker of his identity. The grave is entirely dedicated to his art, with the epitaph a quotation from Puccini's opera Madama Butterfly: 33

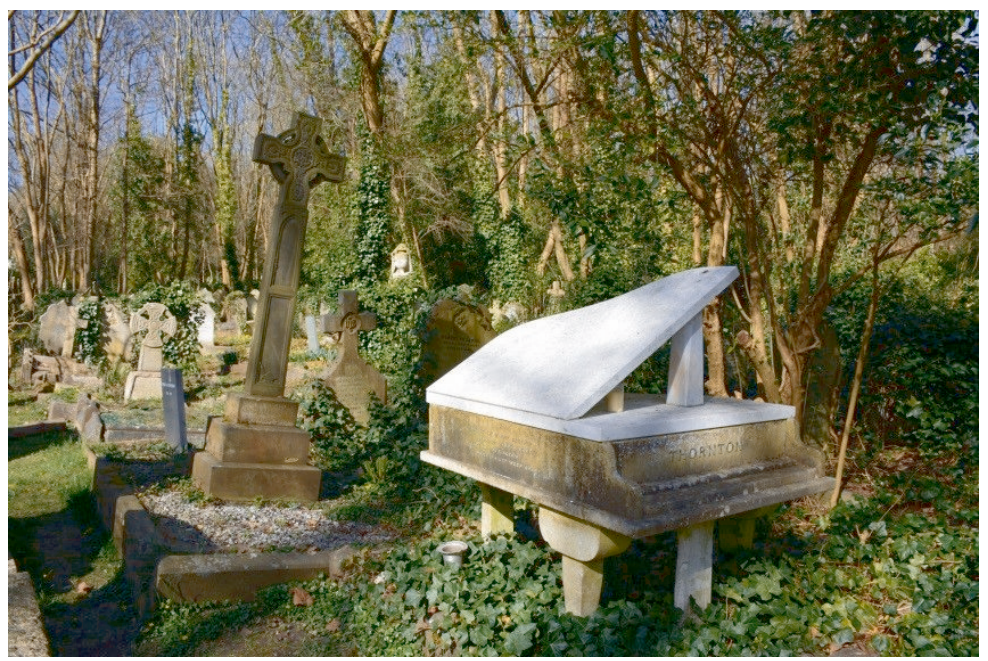

Fig. 10: Grave of Harry Thornton, East Cemetery

(Image: Daria Pezzoli-Olgiati 2017).

\author{
SWEET TH[O]U ART SLEEPIN[G] \\ CRADLED ON MY HEART \\ S[A]FE IN GOD'S KEEPIN[G] \\ WHILE I MUST WEEP APART
}

The piano's presence in this sepulchral landscape locates the deceased according to his social function as a pianist. But the grave symbolises the threshold between life and death, between music that can be performed and the silence of a marble instrument. The grave marker in the form of a musical instrument locates Thornton as a unique individual, but at the same time it refers to the silent realm of the deceased, where uniqueness is exchanged for the common experience of death.

33 Act II, second part, English version from 1906. 


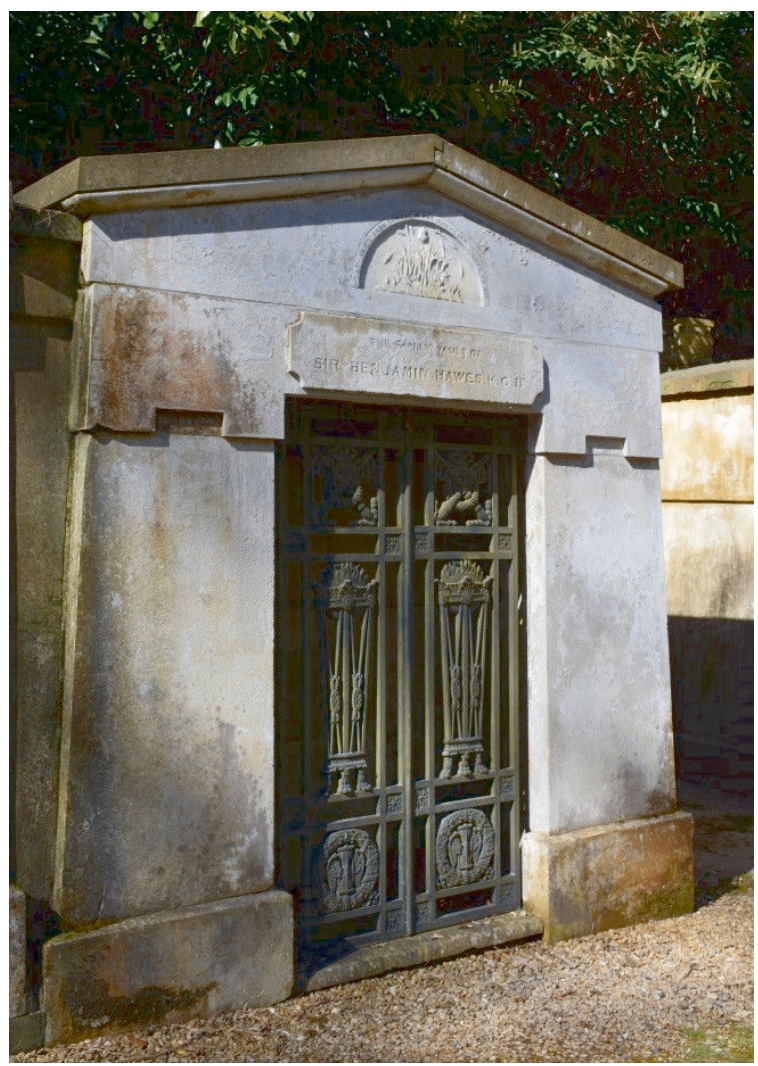

Fig. 11: Family vault of Sir Benjamin Hawes K.C.B., West Cemetery (Image: Daria Pezzoli-Olgiati 2018).

The vault in fig. 11 is a particularly striking example of spatial performativity. Its wording reads:

\section{THE FAMILY VAULT OF \\ SIR BENJAMIM HAWES K.C.B.}

The vault is located in the West Cemetery, exactly on the boundary between the part reserved for Anglicans and the part where Non-conformists are buried. Slightly under the quoted inscription, on the left, in a small incision, it is written "CONSECRATED» and on the right, symmetrically placed, "NON CONSECRATED» (seen from the perspective of a visitor facing the vault). We can therefore assume that the bodies of the members of the family were spatially located in the part of the vault that correspond- 
ed with each individual's religious denomination, Anglicans on the left and Non-conformists on the right. The confessional separation within the West Cemetery marks a continuity with burial practices that preceded the construction of Victorian garden cemeteries. The family vault of Benjamin Hawes (1797-1862), ${ }^{34}$ who served as chairman of Highgate Cemetery, assumes a threshold function physically, socially and symbolically. It unites what in the society of the living has to be separated, but without breaking the spatial and social rules of the cemetery. The austere layout of the vault proposes the equality of the two sides, for it is perfectly symmetrical. Above the inscription a bas-relief of snowdrops, the first flowers to grow at the end of winter and used as a symbol of hope and consolation, ${ }^{35}$ is combined with a quotation from 1 Corinthian 15:36, from a passage that discusses the body in resurrection:

\section{THAT WHICH THOU SOWEST IS NOT QUICKENED, EXCEPT TO DIE}

In life human societies are divided, but in death and in hope for a kind of afterlife all seem equal. The individual must experience death if he or she is to be part of an afterlife. Sharp social distinctions between denominations are annihilated through this particular spatial location and the reference to a shared system of symbols, with a common sacred book and the same eschatological expectations.

A spatial perspective on the tension between the presence of a materialised memory and the absence of the dead illuminates the complexity of the relationships that are enacted by a grave and, more generally, by this cemetery. The need for a physical place to bury the corpse, the negotiation of rules regulating individual, familiar and social difference within a community and the imaginaries of the post-mortem society that inhabits the enclosed landscape are all part of cultural meaning-making processes that arise in the interaction of the materiality of the tomb and the bodily practices linked to it. Those processes are affixed in place, at the locus of the encounter between dead and living.

34 Meller 1994, 164; Boase 2013.

35 See «Spring Flowers», in Golden Hours: A Monthly Magazine for Family and General Reading, March 1883, 163-167 or Dyer 1879, 172; Greenaway 1884, 39; Lehner/ Lehner 1960, 125; Seaton 1995, 194-195. 


\section{Staging Diversity Facing a Common Condition}

When we visit graves in this still-functioning Victorian cemetery, how do images that we encounter affect us? This contribution has explored aspects of the complex field of visual performativity in the particular context of Highgate Cemetery, using an approach that originates in the triangulation of three fundamental concepts in the analysis of visual communication in the study of religion: materiality, body and place. The dynamics and relationships of these concepts have been discussed as we stood before a few selected memorials, from different times and different locations within the site. At the centre of this triangulation lies an anthropological concept of the image and its agency, with the image considered an entity capable of engaging in complex communication processes. Horst Bredekamp has analysed this capacity of images by adapting speech-act theories to visual communication. He points out that «reciprocally to the speech-act, the question for the image-act concerns the power that enables the image when seen or touched to leap out from latency to have external impact in feeling, thinking and action». ${ }^{36}$

The analysis of graves and cemeteries against this theoretical background highlights the role and function of visual communication in the face of a drastic aspect of contingency: life is limited and finite. For a scholar of religion, a Victorian cemetery is particularly interesting as a spatial practice that makes (religious) diversity visible and at the same time harmonises difference. In principle, Highgate Cemetery was conceived for all citizens, in response to social questions about the handling of the dead, and it created a post-mortem circumscribed society within a defined enclosure. Here the members of this society of the dead could be remembered individually and collectively by relatives and/or by society as a whole. Nevertheless, economic considerations, social status, and religious affiliation or ideological orientation played a part in determining the form of burial and memorialization that the dead received. The cemetery stages diversity through material and visual practices.

Each gaze upon a cemetery can only be partial. Time brings decay that sees graves and memorials disappear. The cemetery evolves and changes continuously. Furthermore, in such an imagined short guided tour only fragments of a complex performance can be displayed. A leitmotif has emerged from the examples we have visited virtually, in the tension between death and life, between absence and presence, between the social

36 Bredekamp 2013, 52. 
community of death and remembrance of the unique individual. The graves are part of a social practice in handling death and the dead, whom they necessarily separate from the living. Furthermore, their memorials respond to a need to represent social diversity in a way that is both idealised and harmonised.

«From one year to the next, they say, the Eusapia of the dead becomes unrecognizable. And the living, to keep up with them, also want to do everything that the hooded brothers tell them about the novelties of the dead. So the Eusapia of the living has taken to copying its underground copy.

They say that this has not just now begun to happen: actually it was the dead who built the upper Eusapia, in the image of their city. They say that in the twin cities there is no longer any way of knowing who is alive and who is dead». ${ }^{37}$

\section{Bibliography}

Ahn, Gregor/Sebastian, Emling/Graf, Tim/Heidbrink, Simone/Maréchal, Ann-Laurence/Miczek, Nadja/Rakow, Katja, 2011, Die Tranformation und Konstruktion von Sterben, Tod und Postmortalität, in: Ahn, Gregor/Miczek, Nadja/Rakow, Katja (eds.), Diesseits, Jenseits und Dazwischen? Die Transformation und Konstruktion von Sterben, Tod und Postmortalität, Bielefeld: transcript, 11-41.

Assmann, Aleida, 2010, Re-framing Memory. Between Individual and Collective Forms of Constructing the Past, in: Tilmans, Karin/Vree, Frank van/Winter, Jay (eds.), Performing the Past. Memory, History, and Identity in Modern Europe, Amsterdam: Amsterdam University Press.

Barker, Felix/Gay, John, 1984, Highgate Cemetery. Victorian Valhalla, Salem: Salem House.

Barloewen, Constantin von, 2000, Der lange Schlaf. Der Tod als universelles Phänomen der Weltkulturen und Weltrelligionen, in: Barloewen, Constantin von (ed.), Der Tod in den Weltkulturen und Weltreligionen, Frankfurt a. M.: Insel, 12-119.

Barnard, Sylvia M., 1990, To Prove I'm not Forgot. Living and Dying in a Victorian City, Manchester: Manchester University Press.

Beach, Darren, 2013, London Cemeteries, London: Metro Publication. 
Belting Hans, 2000, Aus dem Schatten des Todes, in: Barloewen, Constantin von (ed.), Der Tod in den Weltkulturen und Weltreligionen, Frankfurt a. M.: Insel, 120-176.

Belting, Hans, 2011, Anthropology of Images. Picture, Medium, Body, trans. Thomas Dunlap, Princeton: Princeton University Press.

Benkel, Thorsten, 2012, Die Verwaltung des Todes. Annäherungen an eine Soziologie des Friedhofs, mit einem Beitrag von Matthias Meiztler, Berlin: Logos.

Boase, George Clement, 2013, Hawes, Sir Benjamin (1797-1862), Dictionary of National Biography, 1885-1900, vol. 25, in: https://en.wikisource.org/wiki/ Hawes,_Benjamin_(DNB00) (accessed June 18, 2018).

Bredekamp, Horst, 2013 (2010), Theorie des Bildakts, Frankfurt: Suhrkamp, $3^{\text {rd }}$ ed.

Boehm, Gottfried, 2001 (1994), Die Wiederkehr der Bilder, in: Boehm, Gottfried (ed.), Was ist ein Bild?, München: Wilhelm Fink, 11-38, $3^{\text {rd }}$ ed.

Bulmer, Jane, 2014, Highgate Cemetery. Saved by its Friends, Norwich: Highgate Cemetery/Jigsaw Design \& Publishing Ltd.

Calvino, Italo, 1974, The Invisible Cities, trans. William Waever, San Diego/New York/London: Harcourt Brace.

Chwalkowski, Farrin 2016, Symbols in Arts, Religion and Culture. The Soul of Nature, Newcastle upon Tyne: Cambridge Scholars Publishing.

Curl, James Steven, 1972, The Victorian Celebration of Death, Detroit: Partridge.

Danani, Carla, 2013, Abitanti di passaggio. Riflessioni filosofiche sull'abitare umano, Roma: Aracne.

Greenaway, Kate, 1884, Language of Flowers, illustrated by Kate Greenaway, printed in colours by Edmund Evans, London: George Routledge and Sons.

Happe, Barbara, 2003, Ordnung und Hygiene. Friedhöfe in der Aufklärung und die Kommunalisierung des Friedhofswesens, in: Arbeitsgemeinschaft Friedhof und Denkmal/Zentralinstitut und Museum für Sepulkralkultur Kassel (eds.), Raum für Tote. Die Geschichte der Friedhöfe von den Gräberstraßen der Römerzeit bis zur anonymen Bestattung, Braunschweig: Thalacker-Medien 2003, 83-110.

Fischer, Norbert, 1996, Vom Gottesacker zum Krematorium, Köln: Böhlau.

Fischer, Norbert/Herzog, Markwart (eds.), 2005, Nekropolis. Der Friedhof als Ort der Toten und der Lebenden, Stuttgart: Kohlhammer.

Gibran, Kahlil, 1923, The Prophet, New York: Alfred A. Knopf.

Lehner, Ernst/Lehner, Johanna, 1960, Folklore and Symbolism of Flowers, Plants and Trees, New York: Tudor Publishing Company.

Löw, Martina, 2001, Raumsoziologie, Frankfurt a.M.: Suhrkamp.

Macho, Thomas, 2000, Tod und Trauer im kulturwissenschaftlichen Vergleich, in: Assmann, Jan, Der Tod als Thema der Kulturtheorie, Frankfurt a.M.: Suhrkamp, 89-120.

Meller, Hugh, 1994, London Cemeteries. An Illustrated Guide and Gazeteer, Aldershot: Scolar. 
Ornella, Alexander D./Knauss, Stephanie/Höpflinger, Anna-Katharina (eds.), 2014, Commun(icat)ing Bodies. Body as a Medium in Religious Symbol Systems, Zürich: TVZ/Nomos: Baden-Baden (London: Bloomsbury 2015).

Philpot, Terry, 2013, 31 London Cemeteries to Visit Before You Die, Brighton: Step Beach Press.

Rugg, Julie, 2007, Outside the Edict. The Chaotic Nature of Burial Culture in the United Kingdom. in: Denk, Claudia/Ziesemer, John (eds.), Der bürgerliche Tod, Städtische Bestattungskultur von der Aufklärung bis zum frühen 20. Jahrhundert/Urban Burial Culture from the Enlightenment to the Early 20th Century, Regensburg: Schnell \& Steiner, 11-16.

Rutherford, Sarah, 2008, The Victorian Cemetery, Oxford: Shire Publications.

Sayer, Duncan, 2011, Death and the Dissenter. Group Identity and Stylistic Simplicity as Witnessed in Nineteenth-Century Nonconformist Gravestones, Historical Archaeology 45/4, 115-134.

Seaton, Beverly, 1995, The Language of Flowers. A History, Charlottesville/ London: University Press of Virginia.

Thiselton Dyer, Thomas Firminger, Flowers and Their Fok-Lore, in: The Leisure Hour, 15.3.1879, 172-174. 
